\title{
Histopathology of Citron (Citrus medica) Infected With Sphaeropsis tumefaciens ${ }^{1,2}$
}

\author{
Sol D. Rodríguez, Rocío Rodríguez and Pedro L. Meléndez ${ }^{3}$
}

ABSTRACT

The host-parasite of citron (Citrus medica L.) and the fungus Sphaeropsis tumefaciens, causal organism of the citrus knot disease, were studied. Conidial germination was observed $\mathbf{4}$ hours after inoculation. Initial movement through the cortex occurs by mechanical action of the germination tube. Knot development started 25 days after inoculation. Hyperplasia and hypertrophy of cells in the deformed area were observed. Invasion of tissues by the pathogen is indiscriminate in all stem tissues, with inter- and intracellular penetration of cells in the infected areas. All tissues invaded by the fungus appeared completely necrotic 75 days after inoculation.

\section{INTRODUCTION}

Symptoms of citrus knot disease caused by Sphaeropsis tumefaciens Hedges have been described by Hedges and Tenny (2) and Rodriguez and Meléndez (4). The deformations, typical of the disease, located along the stem and the branches of the affected trees, suggest neoplasia in infected tissues, which ultimately causes impairment in host structure and function as evidenced by the decline of limbs above the knots. Although as early as 1912 Hedges and Tenny (2) reported on the colonization by this pathogen in orange and lime stem tissues, no reports are available describing the events involved in the development of disease symptoms or how $S$. tumefaciens elicits these effects on susceptible hosts.

The present research was conducted in an attempt to trace the pathogenesis of $S$. tumefaciens and to study the development of knots as observed through histology.

\section{MATERIALS AND METHODS}

Paraffin paper cups were made and tied around the stem at the fourth internode, starting from the apex of the main axis of 3-month-old plants grown in the greenhouse. Each cup was filled with $2 \mathrm{~cm}^{3}$ of a conidia suspension containing $140 \times 10^{4}$ conidia $/ \mathrm{cm}^{3}$. Inoculum was prepared by scraping the surface of sporulating 8-day-old cultures grown at $28^{\circ} \mathrm{C}$ in

${ }^{1}$ Submitted to Editorial Board June 18, 1984.

${ }^{2}$ Part of a thesis for the Graduate School in partial fulfillment of the requirements for the Master of Science degree in Crop Protection. This research was sponsored by Agricultural Experiment Station Project C-486.

${ }^{3}$ Graduate Student, Assistant Phytopathologist, and Phytopathologist, respectively, Crop Protection Department, College of Agriculatural Sciences, University of Puerto Rico, Mayagüez, P. R. 00708. 
Czapek solution agar (Difco) $)^{4}$ to which $50 \mathrm{~cm}^{3}$ of sterile distilled water was added. The conidia thus suspended were collected in flasks after they were filtered through cheesecloth. After inoculation all plants were covered for $72 \mathrm{hr}$ with transparent polyethylene plastic bags. Samples of $0.5 \mathrm{~cm}$ were taken from the treated area of the stems and fixed in FAA (formaline, glacial acetic acid, ethyl alcohol). These pieces were harvested at different intervals (table 1 ) and prepared for the paraffin method as described by Johansen (3). "Paraplast plus" $56-57^{\circ} \mathrm{C}$ was used as embedding material. Sectioning was performed at $5 \mu$ and $10 \mu$ by means of a rotary microtone. Hard samples were softened with a phenol solution (1). Ribbons were mounted on slides with Haupt adhesive (2) and counter-stained with safranine and fast green (5). Events of the patho-

TABLE 1.-Distribution of sampling periods for host-parasite studies of S. tumefaciens in citron

\begin{tabular}{cccc}
\hline $\begin{array}{c}\text { Sample } \\
\text { no. }\end{array}$ & $\begin{array}{c}\text { Sampling } \\
\text { periods }^{2}\end{array}$ & $\begin{array}{c}\text { Sample } \\
\text { no. }\end{array}$ & $\begin{array}{c}\text { Sampling } \\
\text { periods }\end{array}$ \\
\hline 1 & $4 \mathrm{hr}$ & 10 & 15 days \\
2 & $8 \mathrm{hr}$ & 11 & 20 days \\
3 & $12 \mathrm{hr}$ & 12 & 25 days \\
4 & $24 \mathrm{hr}$ & 13 & 30 days \\
5 & 2 days & 14 & 40 days \\
6 & 3 days & 15 & 50 days \\
7 & 4 days & 16 & 60 days \\
8 & 5 days & 17 & 75 days \\
9 & 10 days & & \\
\hline
\end{tabular}

${ }^{1}$ Each period was replicated four times.

genesis as well as the mechanisms involved in knot formation were studied.

\section{RESULTS AND DISCUSSION}

Germ tube formation was first detected $4 \mathrm{hr}$ after inoculation, but it was after $48 \mathrm{hr}$ that abundant conidial germination was observed. Unior bipolarly germinating conidia were detected even 5 days after inoculation. Initial movement of this pathogen through cortex tissues is achieved by the mechanical pressure which the hyphae exert over the cells. Knot development started 25 days after inoculation. At this time, cellular enlargement and proliferation associated with the small swellings on the treated area was observed. Evidence indicated that cell hyperplasia and hypertrophy are directly involved in the development of typical

\footnotetext{
${ }^{4}$ Trade names in this publication are used only to provide specific information. Mention of a trade name does not constitute a warranty of equipment or materials by the Agricultural Experiment Station of the University of Puerto Rico, nor is this mention a statement of preference over other equipment or materials.
} 
disease symptoms. The invasion of tissues by the pathogen is indiscriminate since hyphae were observed in all the stem tissues with inter- and intracellular penetration of the host cells.

Sixty days after inoculation, branch decline was observed over the inoculation site. Sections obtained at this time showed mature picnidia at the epidermis, cortex, vascular tissues and pith parenchyma. Such invasion affected the integrity of those tissues as demonstrated when compared with healthy tissues in the non-inoculated controls. Seemingly the profuse colonization of stem tissues is responsible for the impairment of the translocation process in affected limbs; thus, the decline that is often associated with severe infections by this pathogen. All tissues invaded by $S$. tumefaciens appeared completely necrotic and disorganized 75 days after inoculation.

Although invasion by $S$. tumefaciens is indiscriminate, it preferred younger tissues as evidenced by observations of tissues sampled above and below the inoculation sites. Sections obtained from the area above the inoculation site showed invasion of the tissues and hyperplasia in some regions. However, sections obtained from the areas below the inoculation site showed limited invasion of the tissues and absence of neoplasia in the cells of the cortex. Since the younger and more metabolically active tissues are more prone to be invaded by this pathogen, rampant infections should be expected in seasons when citron trees are actively differentiating vegetative buds and developing new growth.

\section{RESUMEN}

La patogénesis del hongo Sphaeropsis tumefaciens se observó en secciones de tejido enfermo tomadas a diferentes intervalos después de inoculado. Cuatro horas después de la inoculación se observó germinación de los conidios. El movimiento inicial en la corteza se lleva a cabo por medio de la acción mecánica del tubo germinativo. La formación del nudo comienza a los 25 dias después de la inoculación y se observa hiperplasia e hipertrofia de los tejidos de la corteza asociados con el área de la deformación. La invasión del huésped por este patógeno es indiscriminada, ya que se encontraron hifas en todos los tejidos del tallo, penetrando tanto intercelular como intracelularmente.

El desarrollo de cuerpos fructíferos tiene lugar en la epidermis y la corteza, el sistema vascular y la médula. En cortes obtenidos en la parte superior del punto de inoculación se observó abundante colonización por el hongo y células hiperplásicas, mientras que bajo el área inoculada, se observó poca colonización en los tejidos. A los 60 días se observó por primera vez la muerte de la rama localizada más arriba del nudo. Luego de 75 días, todos los tejidos de las plantas inoculadas se encontraban desorganizados y completamente necróticos. 


\section{LITERATURE CITED}

1. Berlyn, G. P. and S. P. Miksche, 1976. Botanical Microtechnique and Cytochemistry, The Iowa State University Press, Ames, Iowa.

2. Hedges, F. and L. S. Tenny, 1912. A knot of citrus trees caused by Sphaeropsis tumefaciens Hedges, USDA, Bureau Plant Industry Bull. 247: 1-69.

3. Johansen, D. A., 1940. Plant Microtechnique, McGraw Hill Book Co., New York.

4. Rodriguez, R. and P. L. Meléndez, 1984. Occurrence of Sphaeropsis knot on citron (Citrus medica L.) in Puerto Rico, J. Agric. Univ. P.R. 68 (2): 179-83.

5. Salazar, C. G., 1965. Comparative anatomy of citrus in relation to cold hardiness, Ph.D. Thesis, Univ. of Florida, Gainesville. 